\title{
Language, Communication and Effective Teaching and Learning in Nigeria
}

\author{
Christopher Eziafa Nwabudike (Corresponding author) \\ Department of Language and Communication Studies \\ Federal University, Dutsin-Ma, Katsina State, Nigeria
}

Tel: 234-805-3140-982Ｅ-mail: cnwabudike@fudutsinma.edu.ng

George Nwaorah Anaso (Phd)

Department Of Language and Communication Studies

Federal University, Dutsin-Ma, Katsina State, Nigeria

Gabriel Olofu Ogwuche (Phd)

Department Of Language and Communication Studies

Federal University, Dutsin-Ma, Katsina State, Nigeria

Received: June 5, 2014 Accepted: June 26, 2014 Published: August 8, 2014

doi:10.5296/ijssr.v2i2.5251 URL: http://dx.doi.org/10.5296/ijssr.v2i2.5251

\begin{abstract}
The purpose of this paper is to highlight the centrality of the application of language rules and communication principles in ensuring effective classroom teaching and learning in Nigeria. Learners act or behave according to the information received. And teachers cannot give correct information and in a proper way if language rules and communication principles are down played. Using the Standard Nigerian English (S.N.E) as a framework, the writers posit that a good teacher, whether in the sciences, arts or humanities must have a high level of proficiency in the use of the medium of instruction- English language, as is the case with us in Nigeria. The thrust of this paper therefore is to impress on all teachers, whose medium of instruction is English language, this all important truth, so they can bear it in mind and prepare themselves accordingly to be their best as they carry on with their noble duties.
\end{abstract}


Keywords: language, communication, teaching, learning

\section{Introduction}

Teaching takes place between a teacher and the learners. And the means of teaching is language; in this case, English (Standard Nigerian English). Hall (1968:158) sees language as "the institution whereby humans communicate and interact with each other by means of habitually used oral-auditory arbitrary symbols". The teaching/learning process of course requires that the teacher and the learners interact, and the means of this interrelationship is language. This agrees with Sapir's view of language as "a purely human and non- instinctive method of communicating ideas, emotions and desires by means of voluntarily produced symbols" (Sapir, 1921:8) as the teacher's primary responsibility in class is to communicate ideas to his students. To Block and Trager (1942:5), language is "a system of arbitrary vocal symbols by means of which a social group co- operates". The two facts that stand out in this definition as well as the preceding ones are that language is both verbal (speech) and non-verbal (symbols). Also, language is used for communication.

When the teacher speaks to the students and they respond, we assume that teaching is taking place. But this does not mean that effective teaching is going on, for learning may not be taking place because much depends on what the teacher says, how he says it, and what the learners perceive. This underscores the need for effective communication. What then is communication? It is any means by which a thought is transmitted from one person to another (Chapel \& Read, 1984:1); the process by which one person (or a group) shares and imparts information to another person (or group) so that both people (and groups) clearly understand one another (R. Udall \& S. Udall, 1979:5); it is not just to the giving of information, it is the giving of understandable information and receiving and understanding the message; the transferring of a message to another party so that it can be understood and acted upon (Eyre, 1983:1); the communication process involves all acts of transmitting messages to channels which link people in the languages and symbolic codes which are used to transmit messages, the means by which messages are received and stored, and the rules, customs and conventions which define and regulate human relationships and events (Ugboajah, 1985:2); at all levels in the organization among and between executives, managers, staff personnel, supervisors and foremen and employees, the communication process is continuously in action, conveying information, ideas, attitudes and feelings among individuals (Chruden \& Sherman, 1978:325).

One thing common in all the definitions above is that communication is a process: a transfer of information, ideas, thoughts and messages. It involves a sender (encoder), a receiver (decoder) a message (code) and language (medium) that is understood by both the sender and the receiver. The communication process involves actions, reactions and interaction. Action refers to the initiative taken by someone (a sender) to share information, observations or opinions with others. He may do so by speaking or writing, drawing or gesturing. Reaction is the response to the action taken by the sender. More simply put, the person addressed responds to the sender's initiative of starting the communication. The response given will show whether or not the receiver is willing to take part in the communication encounter. Interaction is concerned with the exchange of messages between senders and receivers. If the receiver is willing to 
participate, he sends his response to the initiator. The response may be verbal or non-verbal: that is he may write, speak or merely carry out an appropriate action. An interaction can involve two or more persons provided those who take part in the encounter share common experiences, codes or symbols. There will then be an exchange of communication among them as long as there is information to share, or ideas and thoughts to put across.

Elements of the communication process involve stimulus: what triggers off the exchange; source or transmitter: the person that initiates the encounter; message: thoughts, ideas, attitudes, intentions or needs which the encoder sends to the receiver (decoder); medium: the form the sender expresses the message - oral, written, non - verbal; decoder: the person or group who receives and responds to the message; feedback: reply of or reaction to the message and; noise: technical term for all forms of obstacles which reduce the amount of information sent by the sender to the receiver. This could be physical, psychological or linguistic. Teaching according to Ayodeji (1998), is the action of someone (a teacher) who is trying to assist others to reach their fullest potential in all aspects of development. Teaching then requires long hours of work and preparation". In the words of Ogwo (1996), "a good teacher is a good speaker. He is a master of the medium of communication. He speaks clearly, audibly and fluently since most members of the community are likely to imitate him in speech". But unfortunately, this is not always the case as there are many teachers today who cannot communicate effectively in English.

Without proper communication, teaching and learning cannot occur. At the heart of the relationship between the teacher and students is the teacher's ability to communicate clearly. Effective communication is about conveying messages clearly, unambiguously and with little or no distortions to other people. It is not only the prerequisite for successful work in the classroom; it also contributes to make the classroom environment lively and enjoyable to students. Cornett-DeVito and Worley (2005) opine that instructional communication competence is the teacher-instructor's motive, knowledge and skill to select, enact and evaluate effective and appropriate verbal and non-verbal, interpersonal and instructional messages filtered by student-learners' perceptions, resulting in cognitive, affective and behavioral student-learner development and reciprocal feedback. It follows then that both the teacher and the learners need a level of proficiency in the language used for the teaching and learning.

\section{Discussion: Implication of Language and Communication Skills in Teaching and Learning}

Teaching/learning takes place when, and as a teacher and the learners interact (communicate). The teacher sends (encodes) the message (code or information) which the learners receive (decode) and respond (send feedback) to. There cannot be teaching or learning without communication. The tool or medium for this communication is language. Language used for teaching in the classroom is verbal and non-verbal (facial expressions, body movements, listening etc.). The official language in Nigeria is English language. The relationship between the English language, culture and education in Nigeria dates back, first, to exploration era which was characterized by the arrival of the British explorers to an area later known as Nigeria; second, the period of trade and commerce which occasioned the increase in 
Anglo-Nigerian cultural contact; third, the time of missionary activities which ushered in Western education and also, the period of colonization marked by full blown entrenchment of British cultural values, education, English language and the attendant sponsoring of Nigerian students abroad and passage of Educational Ordinance of 1926 that gave prominence to the need for a proper use of English (Omole, 2011). It plays a vital role in the nation's building and her engagement in global trade and investment (Tan \& Rubdy, 2008). English language is the medium of instruction especially from upper primary schools as provided by the National Policy on Education (Revised edition, 1981). Textbooks are written, notes taken and examinations administered and written in English. The successful flow of information passed by the teacher to the pupils or students, the effectiveness of the tool or medium (language, in this case English) and the accomplishment of the goal of teaching (learning or change in behaviour) will depend on the following:

\subsection{Proper Planning}

Before going into the class to teach, the teacher must prepare his or her lesson by gathering relevant information about the topic intended for the learners. This enables the teacher to decide on what method to use to deliver the lesson, the level of language and the feedback to expect. This is expected because proper preparation prevents poor performance.

\subsection{Choice of Words and Expressions}

The words and sentences used by the teacher must be those understood by both him and the learners. The teacher must be meticulous enough to ensure appropriateness of the vocabulary and correctness of the grammar used as the reverse may send a wrong signal to the learners and the message misunderstood as a result. The teacher will then have failed to achieve his aim.

\subsection{Clarity of Presentation}

Clear thinking is necessary for clear presentation. A teacher should be a good speaker. He must master the medium of communication. He must speak clearly, audibly and fluently as his objective cannot be achieved if he fails to do so. Whether in writing or speaking, the teacher must put his message across clearly. It is often said that one does not know what he or she is saying if what is being said is not clear to the listener. Failure to present his thought or ideas clearly mars the communication and consequently, the whole efforts of the teacher. In addition, the teacher must help the learners conquer their doubts and fears about communication and encourage them to develop positive attitudes to communicative activities. Here the teacher's role as communication expert, motivator and counsellor come to play.

\subsection{Appropriateness of Atmosphere}

If a teacher is not in a good mood, he is not likely to convey his message (lesson) across successfully as this will mar the communication process. Conversely, if the learners are not in the right frame of mind, they are likely to give the wrong response (feedback) to the lesson. This underscores the need for self control and friendliness on the part of the teacher so as to ensure that both he and the learners are always prepared to give and get the best in every lesson. This is where listening which is an often neglected skill comes to the fore. Good 
communication requires good listening. The teacher himself must be a good listener and also make the students realize the importance of good listening.

\subsection{Provision for Evaluation}

The teacher should not do all the talking or demonstration in class and assume that the pupils or students are following. Also, he should not see himself as the master of all knowledge and the learners as empty vessels that must be filled. He may be wrong to assume so. This makes it necessary for the teacher to evaluate his lesson, not just at the end but progressively. This could take the form of questions or request for contributions and observations.

\section{Recommendation}

Considering the place of language and communication in effective teaching and the overall achievement of educational goals, it is pertinent that the government and stake holders do the following:

i. Ensure that language and communication skills as a course is not only included in the teacher training programme but also made mandatory for the teachers in training to pass it. This also requires that the prospective teachers be properly groomed in all the four receptive and expressive language skills-listening, speaking, reading and writing. This will go a long way to fully prepare the teachers for the very demanding task ahead of them;

ii. Insist that graduates of Colleges of Education and faculties of education pass through oral and written tests to determine their proficiency in the medium of instruction before they are allowed to teach. In addition to this, School management Boards should endeavour to supervise the teachers in class to ensure good lesson delivery in both private and public schools;

iii. Retain good teachers because they are not easy to come by. Consequently, teachers must be motivated by paying them well so they can enjoy their job instead of enduring it. This way, they will remain on the job and grow in it without having to go seeking greener pastures;

iv. Train and re-train teachers through seminars, workshops, conferences and in-service training to constantly equip/acquaint them with current information and world best practices in the profession as teaching requires professionalism;

v. Encourage the use of English language especially at the primary and secondary levels both inside and outside the classrooms. Here the onus rests not only on the teachers but on parents and guardians as well, as it is their responsibility to make their children/wards use the English language at home;

vi. Reward teachers and students who distinguish themselves in the use of the medium of instruction. This can be done on termly or yearly basis. The motive here is to encourage mastery or proficiency in spoken and written English.

vii. Produce good English language and Communication textbooks equipped with all relevant aspects of the language to help learners learn efficiently. Parents on their part should make sure they purchase such books for their children and wards as this will help them improve in 
their studies. And school administrators, both public and private should establish libraries in all the schools and stock them with such good books.

viii. Disabuse the minds of parents and persons who hate or have nonchalant attitude towards the medium of instruction (English).This can be done through public enlightenment campaign and persuasive talks by the teachers and administrators aimed at making students see the benefits of diligently learning and properly using the language;

ix. Provide all other learning resources that facilitate effective teaching and learning. And teachers at the primary and secondary schools should endeavour to make use of the teaching aids to help the learners learn better. They should also organize extracurricular activities like quiz, debate, and essay writing competition for the students to enhance their use of English.

xi. Ensure that schools are built in noise-free places, not in industrial areas. This will minimize distraction and boost concentration and fruitful teaching and learning consequently.

\section{Summary and Conclusion}

In sum, language and communication are indispensable in successful classroom teaching and learning process and grammar is very central in any useful communication as it is the structural foundation of our ability to express ourselves. The more we understand grammar, the more we are able to effectively use it. It fosters precision, detects ambiguity, and exploits the richness of expressions available in English. It helps everyone, teachers and learners of English, and teachers and learners of anything, for all teaching and learning are ultimately a matter of getting to grips with meaning (Crystal, 2004). While it is necessary to know grammar, it is better to write grammatically than not. It is well also to remember that grammar is common speech formulated and usage is the only test (Maugham, 1934). The grammar of English language has great importance and significance in practical life. Unless one has mastered grammar, he cannot speak or write English correctly as English language is closely related to or associated with grammar and is entirely based on it. Proficiency in spoken and written English, can be achieved by:

i. Studying the parts of speech which indeed are the foundation of every grammatical structure-noun, pronoun, verb, adverb, adjective, preposition, conjunction and interjection;

ii. Practising correct sentence construction and rightly applying tense and concord rules;

iii. Acquiring knowledge of different patterns and use of sentence types- simple sentence, compound, complex, compound-complex and multiple;

iv. Reading books and articles written in good English and by experienced communicators;

$\mathrm{v}$. Listening to news and good speakers on the radio and other media:

vi. Keeping vocabulary notebook and updating it regularly;

vii. Using the new words, phrases and other expressions learnt in communication on daily basis (Sybil, 1990);

viii. Getting a simple but good spoken English book as a companion; 
ix. Possibly trying to attend spoken English classes;

x. Watching English movies and Home videos;

xi. Scheduling your time to spend at least one hour a day for developing your communication.

Teachers and learners must strive to become language and communication experts as teaching and learning depend much on this. The recurrent dismal performance of students in public examinations like West African Examinations Council (WAEC), National Examinations Council (NECO), and Joint Admissions and Matriculation Board (JAMB) is not unconnected with teachers' and students' negligence or complacency in this regard. It has become therefore necessary for teachers and learners to ensure their mastery of the medium of instruction (English) as both language and communication are inextricably bound together.

\section{References}

Lyons, J. (1981).Language and Linguistics, An Introduction. Cambridge University Press.

Murthy, J. D. (2007). Contemporary English Grammar. Lagos: Book Master.

Nwabudike, C. E. (1996). Language as a Tool for Effective Communication in the Classroom. A paper presented at the Annual Seminar/Workshop for teachers of Charis Preparatory School, Kano.

Nwabudike, C. E. (2006). Essays on Education and National Development Vol. 1. Kano: Sonat Print.

Nwabudike, C. E. (2012). The Role of Language and Communication skills in Effective Classroom Teaching and Learning. A Paper Presented At The $29^{\text {th }}$ Annual National Conference Organised By The Nigeria English Studies Association (NESA) From $10^{\text {th }}$ To $13^{\text {th }}$ September, 2012.

Ogwo, B. A. (1996). Curriculum Development and Educational Technology. Makurdi: Onaivi Printing and Publishing Co. Ltd.

Omole, K. (2011). English Language, Culture and Education in Nigeria: Issues and Prospects. Journal of the Nigeria English Studies Association (JNESA), 14, 1.

Ogwuche, G. O. (1997). Technique of Passing English Language. LASAPEN Journal of Language and Literary Studies, 1(1), 55-59.

Reddy, B. B., \& Gopi, M. M.(2013). The Role of English Language Teacher in Developing Communication Skills among the Students of Engineering and Technology. International Journal of Humanities and Social Science Invention, 2(4), 29-31.

Richards, J. C.(2002). Methodology in Language Teaching-An Athology for Current Practice. Cambridge University Press. http://dx.doi.org/10.1017/CBO9780511667190

Sng, B. B. (2012).The Impact of Teacher's Communication Skills on Teaching: Reflections of Pre-service Teachers on their Communication Strengths and Weaknessies. In Humanizing Language Teaching.www.hltmag.co.uk, Issue 1. 
Sybil, J. (1990). Introduction to Communication for Business and Organizations. Ibadan: Spectrum Books Ltd.

Williams, D. (1990). English Language Teaching- An Integrated Approach. Ibadan: Spectrum Books Ltd. Retrieved from http.//www.studyguideindia.com/communication-guide

\section{Copyright Disclaimer}

Copyright for this article is retained by the author(s), with first publication rights granted to the journal.

This is an open-access article distributed under the terms and conditions of the Creative Commons Attribution license (http://creativecommons.org/licenses/by/3.0/). 